\title{
E-Parliaments and Novel Parliament-to-Citizen services
}

\author{
Aspasia Papaloi*, Dimitris Gouscos** \\ ${ }^{*}$ PhD Candidate, New Technologies Laboratory in Communication, Education and the Mass Media, University of Athens, 5 \\ Stadiou str., GR-10562, Athens, Greece, apapaloi@media.uoa.gr, +302103689426 \\ ** Lecturer, Faculty of Communication and Media Studies, University of Athens, 5 Stadiou str., GR-10562, Athens, Greece, \\ gouscos@media.uoa.gr, +302103689426
}

\begin{abstract}
In an era of citizens' discontentment on democratic institutions, parliaments as a democratic cornerstone, are constantly striving to create alluring services, whilst taking into account the difficulty of achieving accessibility and transparency in citizens' e-participation. At the same time, the evolution of ICT tools presents opportunities to revamp the traditional character, functions and services of parliaments worldwide, giving rise to new capabilities and opportunities that can transform their political and social role. An e-enabled parliament can not only offer flexibility in parliamentary proceedings and facilitate the work of its members, but also strive for the inclusion of citizens, without annulling the representative character of the institution. In this paper, we present an initial overview of the characteristics of modern parliaments, recording existing service offerings and proposing a stakeholder-based categorization, with specific categories that can best accommodate explicit and active citizen participation within parliamentary functions. A number of existing citizen deliberation applications and research projects are highlighted as potential candidates for deploying novel extrovert parliament-to-citizen services, focused directly on citizen involvement. Moreover, the focus area based on the procedure from inclusion to feedback will give good evidence for all those factors that are necessary for a successful adoption of novel e-parliament services.
\end{abstract}

Keywords: e-parliaments, democracy, parliamentary-like initiatives, parliament e-services, inclusion, awareness, engagement, participation, feedback

S ubsequent form of the Athenian "ekklesia" (assembly) at Pnyx - where laws were enacted by the representatives - is that of the contemporary parliament. Despite the institutional differences concerning the function of parliaments - or in cases of regimes which apply direct democracy -, a parliament's obligation is to enact laws, to exercise parliamentary control and represent citizens. This last characteristic creates a two-way relationship between parliaments and citizens.

Nowadays, parliaments are trying to maintain this two-way relationship with the implementation of parliamentary-like initiatives that are similar to the legislative function of the parliament. Moreover, the introduction of Information and Communication Technologies (ICT) has enabled the enrichment of those initiatives, in order to advance participatory democracy. This venture is quite intriguing and promising for parliaments and citizens. In terms of the parliaments, this is a good opportunity to prove that they act in a transparent and democratic way and parliamentarians can be accountable to the electorate. In terms of the citizens, this is an occasion to make their voices heard and hope that their recommendations will be taken into account.

Nevertheless, the reality is different than it seems. The implementation of ICTs for the creation of e-parliament services is not a simple venture. The success of such an attempt depends on several factors, which are ranging from the available ICT tools to human potential variables. The adoption of the appropriate e-services depends mostly on strategic planning, but also on the examination of factors such as inclusion, awareness, citizen engagement and citizen participation. Feedback is a deciding factor, in order to prove this, it is essential to establish a functional and actual bidirectional relationship between parliamentarians and citizens, with the aim to foster participatory democracy and to implement successful e-parliament services. 


\section{An agenda for modern democratic parliaments}

\subsection{The role of parliaments in democracy}

Searching references from past and present bibliography, as far as the definition of the terms 'parliament' and 'democracy' are concerned, it has been concluded that these two terms are connected. As Anders Johnsson (2006)', IPU General Secretary, mentions "parliament is the central institution through which the will of the people is expressed, laws are passed and government is held to account" (Beetham, 2006, p.viii).

Furthermore, Cheibub and Limongi (2002) in their research about parliamentary and presidential democracies, conclude in the following definition: "The fusion of powers characteristic of parliamentarism is supposed to generate governments capable of governing because they would be supported by a majority in parliament, composed of highly disciplined parties prone to cooperate with one another, which, together, would produce a decision-making process that is highly centralized".

These definitions help highlight the multidimensional role for a modern democratic parliament. According to Beetham (2006) and Armit (2007), following distinctions can be proposed not only as far as the characteristics of a democratic parliament are concerned, but also to the delineation of a parliament's role as a medium for public engagement, inclusion and connection with government, as far as parliamentary initiatives are concerned:

- Its members' role: This implies that the members of parliament are "accountable to the electorate for their performance in office and integrity of conduct";

- Its institutional role: This presupposes that a parliament is "socially and politically representative of the diversity of the people, and ensures equal opportunities and protections for all its members";

- Its operational role: This means that a parliament must be effective and "produce better laws, policies and programs" in a manner that its "legislative and oversight functions serve the needs of the whole population";

- Its technological role: This means that a parliament is "open to the nation through different media, and transparent in the conduct of its business";

- Its educational role: This presupposes that a parliament is accessible, which means involvement of "the public, associations and movements of civil society in the work of parliament". This refers not only to civic participation, but also to citizenship education by helping citizenry understand the value of parliamentary institutions through the democratic process;

- Its connective role: This role refers to a triangular connection among parliament, citizens and government and intends: (i) to the building of trust between government and citizens, because "the more citizens know about what is happening in government, the more they understand the limitations of government and the role they play in it", and (ii) to the strengthening of legitimacy of governance, because "it facilitates policy and program implementation and promotes voluntary compliance with laws" (Beetham, 2006, p. 7; Armit, 2007, pp. 2-3).

All these characteristics imply that a parliament is the medium for citizens' expression and connection with the elected representatives. Indeed, meeting these prerequisites is a high and difficult priority of a parliament, so as to be proven sustainable and functional not only as far as the performance of its parliamentarians and the 'production' of better laws are concerned, but also pertaining its role as an institution that fosters representative democracy by educating and embracing its citizens. On the other hand, the elected representatives should evoke the feeling in their constituents that their rights are protected and represented and the collective security and prosperity is ensured.

Speaking of representation, Pantelis (2007) contends that the system of representative democracy is dominant to the direct one, because: (i) "the elected representatives decide on issues 
of major importance", (ii) "the representative system protects efficiently citizens' minority against majority's oppression", (iii) "citizens need elected representatives, because those are the competent ones to the problem solving of public importance issues" (p. 98). In other words, the supremacy of the representative democracy seems to depend not only on the constituents' right to elect the most appropriate and capable representatives, but also on citizens' trust to be represented in a parliament, due to the fact that it is impossible for each constituent to express their opinion and be taken into account pertaining the decision making.

Of course, the sense of popular sovereignty is quite present in direct democracies and the referenda held for decision-making advocate transparency. Nevertheless, in some issues - i.e. fiscal or budgetary ones - citizens are incompetent to decide, because in such cases, proper governmental maneuvers in order to cope with the complexity of the issues are needed. Suffice to say, that the transition of representative democracies into direct ones might endanger: (i) the credibility and sustainability of governments and (ii) the importance of national elections by weakening the political representation and lead to phenomena of populism, namely the emergence of ochlocracy.

\subsection{Parliaments as a facilitator for engaging citizens in active participation}

Nowadays a lot of parliaments worldwide are engaging citizens in discussing social issues, in participating actively in parliamentary events and, in some cases, making their voices heard. Searching relevant webography and bibliography about activities organized by parliaments has led to the conclusions that such activities are usually structured similarly to parliamentary procedures and aim at the participation and interaction of citizens on social and political issues. Two examples of such activities are the 'Youth Parliament' and the 'Elders' Parliament' programs, which will be further analyzed.

Following parliament-like initiatives depicting the educational role of a parliament in the context of civic education and acting as a means of fostering citizens' understanding, pertaining the value of parliamentary institutions via democratic processes.

\section{Parliamentary-like initiatives for citizen engagement}

Several governmental and non-governmental institutions worldwide take the initiative for the organization of parliamentary-like programs for citizen engagement. Further, is presented a categorization of those initiatives according to age groups, demographic criteria or issues to be discussed among citizens. The implementation of such initiatives - besides the age group parliaments - is not directly connected to parliaments, but their intention unveils the needs of citizens for active participation and for making their voices heard by parliaments and by governments in general.

\subsection{Age-group parliaments}

'Youth Parliament' programs are implemented by many parliaments worldwide. Such a program requires the physical presence of adolescents and their interaction, operating as a simulation of parliamentary proceedings and giving the chance to adolescents to discuss social issues in two levels: (i) in committee meetings, and (ii) in a Plenary session. Several parliaments also use ICT tools such as blogs, e-polling, fora, chat etc. in their educational portals, in order to enhance 'Youth Parliament' programs.

The main objective of an 'Elders' Parliament' program, on the other hand, is to discuss the problems of the elderly. Such a program, for instance, is organized by the parliament of Cyprus.

\subsection{Social parliaments}

An example of a 'social parliament' type of activity is the 'Citizens' Parliament' program, which has taken place in Australia. According to Blackadder (2009), "a citizens' parliament involves a 
large group of randomly selected citizens (...) coming together to listen, learn, reflect upon and discuss an issue of public importance. Through this transparent process of deliberation, they produce recommendations for those in leadership that reflect the considered views of the broader community. The mission of deliberative processes like citizens' parliaments is to change the way people talk about politics and make political decisions" (p. 3).

\subsection{Thematic parliaments}

A very good example of what can be termed a 'thematic parliament' is that of a pilot program organized by the European Commission under the title 'European Citizens' Panel'. This initiative has engaged people from several European regions to discuss the future role of rural Europe and relevant issues. According to the summary report of the EU Committee of the Regions (2007), this project has aimed to further "(...) innovative participatory process, with potential wider application, that can re-energise the contemporary governance of European affairs" (p. 3).

\subsection{Alternative parliaments, counter-parliaments}

The terms of 'alternative parliament' or 'counter-parliaments' - usually found in blog spots, online newspapers or websites - are mainly used to indicate the need of a citizen group to express itself through a different milieu. An objective of this kind of 'parliament' is to structure citizens' protest on current social issues or their participation in the current political agenda.

As mentioned above, the implementation of these initiatives serves the engagement of citizens in order to become familiar with the democratic procedures. Of course, the success of these parliament-like initiatives depends on the level of deliberation that will be achieved among citizens and the impact that this deliberation will have on the elected representatives of a parliament. In the same line of thought, this speculation is clearly stated in Citizens' Parliament final report, but it is not clear if the recommendations of citizens are taken into account by governments. Characteristically, it is mentioned that the initiative "was not convened by government, so no guarantee was offered to participants about the uptake of their recommendations" (Blackadder, 2009 , p. 43). Here has emerged an issue of major importance, which is linked with the issue of direct and representative democracies and the question, if governments are obliged to disseminate citizens' views. As mentioned above, the purpose of representative systems' existence and the elections' in general, lies in the ability of citizens to 'recognize' and elect the most appropriate and capable representatives. But, what happens if the elected representatives do not meet the needs of their constituents? In contemporary democracies we rarely hear about referenda as a medium for citizens' expression. So, the existence of these parliamentary-like initiatives is imperative not only for the understanding of parliamentary procedures by the citizens; it is a way for elected representatives to watch closely and 'eavesdrop' on how citizens feel, think, and act about everyday issues and problems. In our opinion, the parliamentarians should take into account, to some extent the recommendations of their constituents. Otherwise this will inevitably lead to unstructured forms of citizens' participation or even to anarchist forms of expression. These kinds of citizen participation can result either in a country's instability, or in ochlocracy and anarchy.

The 'thin red line' between citizens' recommendations and the extent of their adoption by the members of a parliament should be handled carefully and transparently, so as not to endanger the excess of representatives within democracy's limitations. On the other hand, this adoption should not be made with arbitrary judgment. This means that all opinions and recommendations should be presented, carefully examined and evaluated before the parliamentarians decide which of them can be adopted, in order to formulate and implement new policies. Of course, this can be achieved through the already implemented parliamentary-like initiatives as shown above. These initiatives can be evolved significantly with the participation of parliamentarians and by giving substantial feedback to their constituents. Feedback can act as the crowning of this organized venture, which encompasses inclusion, awareness, engagement and participation of the citizens. In other words inclusion, awareness, engagement and participation constitute the procedure, which attracts and 
enables citizens to express their opinion and propose some recommendations. Feedback is the outcome of this procedure and depends on the deputy of each constituency to decide whether to adopt or reject these recommendations. In any case, the rejection, the adoption or the modification of citizens' recommendations should always be justified by the elected representatives.

This kind of cooperation between the members of a parliament and the electorate will avail in multiple ways by: (i) helping the government to identify better the needs and the problems of the society, (ii) enabling the parliament to produce better laws, (iii) enabling the members of a parliament to gain support and approval by their constituents, (iv) ensuring transparency (v) giving the opportunity to the citizens to act in organized groups, (vi) giving the citizens the opportunity to be cooperative, to respect the opinions of other constituents, to substantiate their arguments and act as responsible members of the society, and (vii) ensuring the stability of the society. In other words, the stability of the state is secured, because citizens express themselves in organized forms of participation, the state maintains a better control of these participation forms by discouraging the creation of unstructured forms/groups of expression, which can lead to populism.

Further, will be discussed the concept of e-parliaments incorporating the above mentioned criteria into e-services.

\section{E-Parliaments and citizen services}

\subsection{The concept of E-Parliaments}

The implementation of ICT in parliaments has formed a new concept and role for parliaments, that of an 'electronic parliament' or 'e-parliament'. "An early definition from the European Centre of Parliamentary Research and Documentation (ECPRD) focused on the organisational aspects of parliament, where relevant stakeholders and processes (...) interact through the use of modern information and communication technologies and standards 'in order to achieve transparency, quality, throughput, efficiency and flexibility"' (United Nations, European Parliament, Global Centre for ICT in Parliament, 2008, p.11).

The World E-Parliament Report (2008) focuses on the institutional approach of the 'e-parliament' concept and the application of modern technologies:

"One can (...) define an e-parliament as a legislature that is empowered to be more transparent, accessible and accountable through ICT. It empowers people, in all their diversity, to be more engaged in public life by providing higher quality information and greater access to its parliamentary documents and activities. It is an organisation where connected stakeholders use information and communication technologies to support its primary functions of representation, law-making and oversight more effectively. Through the application of modern technology and standards and the adoption of supportive policies it fosters the development of an equitable and inclusive information society" (United Nations et al., 2008, p.12).

The abovementioned definitions depict not only the characteristics mentioned in the previous section about the multidimensional role of a contemporary democratic parliament; they also portray the twofold role of a parliament using ICT technologies by revealing its possibilities in the levels of inward sustainability and outward inclusion. The 'e-parliament' concept creates opportunities for a functional and effective administration within a parliament's scope by overcoming bureaucracy obstacles. Moreover, this concept goes beyond the physical participation of parliamentary-like initiatives by introducing a wide range of interesting e-services, which are attractive and are able to engage more citizens than usual. The availability of these e-services - enabling citizen engagement and participation - should not be granted as a replacement of parliamentary-like initiatives conducted in a physical context, but as a supplementary activity, which includes a wide range of citizens and engages them with different kinds of projects, according to the way they want and can interact.

The following two subsections will be present how ICT is introduced and implemented in the parliamentary context, according to the two aforementioned levels. 


\subsection{Parliamentary websites}

The Inter-Parliamentary Union (IPU) (2009), based on a previous guidelines' edition on parliamentary websites, suggests a best practice guide for parliamentary websites, incorporating up-to-date ICT tools and e-enabled practices. This manual was based on a global parliamentary survey including several parameters, with the aim to enhance the twofold role of parliamentary websites: (i) to enable the accessibility of visitors in finding information about legislative work and (ii) to facilitate the work of the members of parliament. Corresponding guidelines are organized in the following sections:

- 'General information about parliament', referring to past and current information about the function, composition and activities of a parliament, its location and access, as well as administrative details, information services and links to relevant websites;

- 'Information about legislation, budget, and oversight', referring to the actual works of a parliament and including information on the functions and activities in question;

- 'Finding, receiving, and viewing information' with respect to tools that website visitors can use in order to obtain information;

- 'Communication and dialogue with citizens', with reference to tools such as "general feedback and communication between members and citizens";

- 'Usability, accessibility, and language', related to design issues that ensure easy and pleasant access for citizens from all walks of life;

- 'Management and responsibilities', referring to issues "dealing with authority and responsibility, resources and support, strategic planning, roles, the management of documentation and information, and publicity about the website".

This categorization constitutes a useful guide to all parliaments, assuring the ability to cope with such issues as political will and support for transparency of parliamentary proceedings, availability of the budget necessary for implementation, citizens' technological literacy as well as multi-lingual translation of website services and relevant documentation. The recent redesign of the Hellenic Parliament website is a characteristic example and has adopted the up-to-date IPU guidelines. According to these principles, this website shows its 'extrovert character' giving the opportunity for citizens to follow up the everyday parliamentary activity of the Speaker, of the committees' meetings, of the legislative work and the parliamentary control, accompanied by a feasible plan of extracting press releases, minutes and reports. Moreover, it enables the connection with web TV for the broadcast of plenary or committees' sittings. What is more, the parliamentary personnel have been trained to follow up and update their directorate's activities.

Going beyond this example, concerning the data appearing on a parliamentary website, a recent survey conducted by the Global Centre for ICT in parliaments gives tangible data about the "communication between citizens and parliaments", and it holds the lowest score (approx. $28 \%$ ). According to the extracted results, reasons for this low ranking may be: (i) the recent emergence of communication technologies, (ii) the lack of the know-how of parliament stakeholders, in order to put into effect the interaction with citizens and also (iii) "institutional and procedural constraints (that) need to be overcome for their implementation" (United Nations \& Inter-Parliamentary Union, 2010 , p. 133). Of course, the issue of institutional and procedural constraints raises some critical questions such as: are parliaments willing to foment a political change by means of adapting to new forms communication? How is this political change going to affect the existed balance among parliaments, governments and citizens? Although these issues were justified to some extent in a previous section, this point has ignited a discussion that falls beyond the scope of this chapter and belongs to the sphere of political and law science. Going back to the first two reasons that have been just mentioned, there is a strategic plan to be followed in order for parliaments to provide feedback to citizens and which will be further analyzed and discussed. 


\subsection{E-Parliament services}

The essential offerings of a parliamentary website are the end services provided, rather than the tools employed. What is more, modern e-parliaments need to be able to offer services not only to the government, but also to groups and citizens and non-governmental organizations. As far as the creation and implementation of such services is concerned, our research has concluded that, for the time being; only some e-services are created and implemented by parliaments, while others are created and performed by non-governmental organizations, universities or institutions of the European Union. With such a view, e-parliament services can be categorized as follows:

- 'Parliament-to-Parliament (P2P) services': Parliament-to-Parliament services refer to those technological applications that can be used to facilitate information exchange between parliaments, mentioning the 'Inter-Parliamentary EU Information Exchange' (IPEX) service as an example. According to the IPEX Brochure (n.d.), IPEX is a database storing "(...) parliamentary documents pertaining to the national scrutiny of decisions taken at the EU level" with the objective of "(i) facilitating the exchange of all EU-related information between parliaments, (ii) providing fora for the exchange of views on scrutiny including subsidiarity $^{2}$ aspects, and (iii) maintaining a Calendar of interparliamentary meetings";

- 'Parliament-to-Members of Parliament (P2MP) services': Parliament-to-Members of Parliament (MPs) services refer to ICT tools that can be used to facilitate the work of parliamentarians. As a survey of ECPRD has showed, the most highly ranked services used by MPs are those of mobile technology, webmail, remote access to legislative documents and the use of laptop computers (United nations et al., 2008). As far as mobile technology is concerned, the Finnish Parliament facilitates a number of loan library services via mobile phone including SMS notifications for availability of requested material, loan period expiry/renewal as well as requests to the Information Service (The Library of Parliament, 2007). Moreover, the use of mobile services has facilitated the work of MPs and civil servants while on the move, through GPRS data services on their mobile phones (Teliasonera, 2005), as well as, automated calendar and event notifications (Fujitsu, n.d.);

- 'Citizens-to-Parliament (C2P) services': This category refers to services available to citizens in order to contact their MPs and give further feedback to parliament. A good example of such services is offered by the UK-based 'MySociety' projects, which aim to "give people simple, tangible benefits in the civic and community aspects of their lives" (UK Citizens Online Democracy). In the 'Hear from Your MP' service, citizens can enter some personal data (name and postal address details) to be included in a list of people in the same constituency. When enough citizens have signed up, service administrators send e-mails to let the MPs know that they have to reply to their constituencies about their plans. MPs are able to answer and ask citizens for further proposals, thus turning this online message exchange into a discussion threadii. In the same line of thought, the 'They Work for You' ${ }^{3}$ and 'Write to Them, ${ }^{4}$ projects constitute a kind of simply structured and easy to conduct e-petitions. Their brand names are intentionally formulated with a view to encourage citizens to participate and, either follow up the work of the preferred MP ('They Work for You'), or send an e-mail asking for information about an issue of their interest ('Write to Them');

- 'Parliament-to-Citizen (P2C) services': This category includes new projects that can be implemented by parliaments with the intention to attract citizens' interest and participation in parliamentary proceedings. Such an example is that of the "e-Petition Project" of the Scottish Parliament, which was created by the University of Napier.

- Parliament -to- Media (P2M) services: A characteristic example of a Parliament-to-Media service is that of the Hotline-Newsdesk, a service established by the European Parliament, which provides to journalists useful information on several programs, projects, briefings or activities of the European Parliament (Staiou, Papaloi \& Gouscos, 2010).

The aforementioned examples depict state of the art already implemented e-services and the degree of progress in e-parliament services worldwide. These e-services not only facilitate the 
everyday parliamentary procedures, but also connect parliaments with citizens and journalists. Referring to the communication between parliaments and citizens and, in accordance with the eservices described, the following questions emerge: Are parliaments willing and capable of creating e-services, according to the needs and preferences of the citizens/constituents? If yes, in what way do they intend to manage them and what are the expected results? All these questions presuppose a real interest in terms of the parliament stakeholders and strategic planning in order to attract citizens' interest. First and foremost, this venture -except for its complication and the coordination of actions - presupposes the discovering of feasible and original solutions for citizens' attraction by parliament stakeholders, given the feeling of general discontentment and distrust of citizens towards parliamentarians and democracy, in general.

Moreover, it is worth mentioning that the existence of the IPEX database constitutes an excellent example of inter-parliamentary cooperation. According to the World e-Parliament Report (2010), it is stated that "inter-parliamentary cooperation and exchange of knowledge and ideas for the progress of developing legislatures", "further contribution of other development factors except for parliaments" as well as "a constant collaboration and exchange of knowledge and ideas in regional and international settings" compose a number of factors for achieving a greater degree of sustainable and responsive e-parliament services (United Nations et al., 2010, pp. x-xi). This fact implies that implementing e-parliament services is a venture that calls for a well-organized strategic plan, it is a complicated concept that demands constant labour and feedback among several stakeholders, yet achievable and promising for the promotion of e-participation.

Except for the e-parliament services - which are already implemented within the everyday parliamentary procedure and in different levels (e.g. P2P, P2C, C2P etc.) - further examples of pilot projects that run in real world settings will be presented, including e-rulemaking, participatory budgeting, argument visualization and discussion visualization services, as well as the implementation of serious games and social media techniques.

\section{Towards novel E-Parliament services}

Based on the current state of play in citizen deliberation services, some promising projects are introduced in this section, which can in turn be introduced by parliaments in order to promote citizens' engagement in different ways. All-in-all these projects, which are already running in realworld settings or are currently being researched, can pave the way towards a new era of citizen involvement in parliamentary decision-making and their implementation will need to be coupled with evaluating, among other factors, the citizens' needs, priorities and abilities as well as the capabilities of each parliament for managing the necessary financial and human resources.

\subsection{E-Rulemaking}

The 'E-Rulemaking' concept, mainly developed in the US, serves as a medium "for citizens in order to submit comments electronically and deliberate interactively over pending rulemakings" (Coglianese, 2004, p. vii) and can be implemented by using existing technological tools. The goals of such a project are "the increase of democratic legitimacy and regulatory compliance, the improvement of policy decisions and the decrease of administrative costs" (Coglianese, 2004, p. vvi). Although such a venture sounds complicated, the advancement of technology has enabled more transparency on citizens' rulemaking proposals, whereas rulemaking agencies are becoming familiar with the corresponding tools. Such a project brings forward a significant potential for improving regulatory decisions, increasing the quality of government rules and giving rise to new eservices such as digital libraries and others (Coglianese, 2004).

\subsection{Participatory budgeting}

The 'Participatory Budgeting' (PB) concept has been implemented by several communities (at the municipality, or higher level) worldwide since 1989, giving the chance to citizens from all walks 
of life "to gain firsthand knowledge of government operations, influence government policies, and hold government to account" (Islam, 2007, p. xv). It is essentially a tool that enables citizens to have their voices heard as far as allocation of public resources is concerned They can also influence policies and participate actively in public decisions. On the other hand, PB projects can broaden citizen awareness of social and political issues, prevent corruption and enforce decisionmaking in democratic regimes. According to Wampler (2007), the groups taking part in participatory budgeting are local governments, individual citizens, civil society organizations, NGOs as well as the business community. The participation of so many stakeholders makes the final decision taken more complex, yet at the same time more credible (Moynihan, 2007), comprehensive and fair.

\subsection{Argument visualization}

The 'WAVE Project' (2009) is based on the 'Debategraph' platform for argument visualization, i.e. for the graphical representation in a shared user space of the arguments formulated during a public dialogue. Proposed in a multi-lingual cross-border context, this project aims at the "inclusiveness and transparency of EU decision making at national and European level (...)" (para. 1). Differing points of view can help participants understand complex debates, whereas the use of wikis can enable citizen collaboration and help develop "integrated (citizen) feedback on legislation" (WAVE Project, 2009, para. 5).

\subsection{Discussion visualization}

The 'VIDI Project' (2009) is based on a discussion visualization platform and aims "to enable a more efficient interaction between citizens and policy makers, by enabling better understanding of the public opinion and its evolvement regarding the proposed or adopted legislations" (para. 1). Using an ICT platform for text visualization of the topics discussed in a public dialogue their "(...) understanding, discovery and summarization" becomes easier (VIDI Project, 2009, para. 1).

\subsection{Serious games}

The introduction of serious games in e-participation is a means of giving players the opportunity to learn, rather than teaching them (Stapleton, 2004). A characteristic example of this kind of serious game is the creation of the VoiceS project, which encompasses semantic applications (i.e. improved search engines instead of keyword-based search, query answering instead of information retrieval, cloud tagging), social network profiles and serious games (VoiceS Project, 2008). According to Holzner, Schepers, Scherer and Karamagioli (2009), this game can enable players to explore the EU co-decision procedure by taking different roles and enabling them to learn about a legislative issue.

\subsection{Social media}

A quite interesting involvement of social networking sites (SNS) in e-participation is portrayed through the implementation of the WeGov project. Some of its characteristics refer to: the information exchange with social networks, to the development of the appropriate tools for the analysis of online discussions and the automating of communication between citizens and policymakers, to the visualization of discussions with the help of service-oriented models on cloud infrastructures etc. (WeGov Project, 2010).

On the other hand, the HUWY project is closely connected with youth groups and youth parliaments. Young people explore topics of interest in various online spaces, such as blogs, social networks etc., and post their findings on the corresponding Hubs, namely websites with information and outcomes to be used by young people and policy-makers. Further, the extraction of these outcomes enables policy-makers the creation of policies (HUWY Project, n.d.). 
These pilot projects seem to be promising, despite still being in their infancy or being currently researched. Nevertheless, they offer some very useful and promising results through their implementation.

In the case of the e-rulemaking project, research conducted by Schlosberg, Zavestoski and Shulman (2007, p. 50) among participants, who submitted comments on regulation drafts by using (a) contemporary electronic tools or (b) conventional facsimile and postal mail, was not able to conclude if the new electronic systems are more deliberative than traditional means of communication. Still, participants who used electronic submission tools noted that they were able to read each others' comments and this enabled them to better understand other points of view and often change their initial positions. Based on these findings Schlosberg et al. (2007) conclude that there is "no evidence that electronic participation, per se, is any more deliberative or substantive than traditional forms of participation" and add that "citizen participants in general exhibit numerous deliberative attributes, those that engaged the process enough to contribute original comments embodied the highest measures of deliberative activity, and that participants expressed a desire for increased avenues for participation and influence" (pp. 51-52).

Respectively, in participatory budgeting and relative to it initiatives, Bose $(2008$, p. 17$)$ refers to several techniques, such as posting articles pertaining cases of corruption for investigating and tracking budget-related expenditure, providing information to municipal agencies, posting of blacklisted contractors involved in public works, the use of cell phones by farmers and other citizens to keep in touch with government and private vendors for procurement and price information of seeds, fertilisers etc. These techniques, know as m-government (mobile government) services, are usually implemented by middle-income and low-income countries, in order to bridge the digital divide by using ICTs individually or collectively (Nahleen, 2006). These techniques sketch the numerous abilities of the e-services providing evidence that the "one-sizefits-all" approach and application does not fit in this case. In the same vein, this works for eparliament services as well.

This research on pilot projects brings us to the conclusion that these e-services are a medium: (i) for the notification of citizens pertaining a governmental plan or bill, (ii) for a better classification of citizens' opinions (e.g. the "Fixmystreet" initiative), (iii) for the outspoken citizens, (iv) for the facilitation of opinion exchange, (v) for a greater degree of inclusion, awareness, engagement and e-participation, and (vi) for the exercise of democracy in general.

The task of these e-services is to manifest that they do not fall under the tactic of "slacktivism" (a word introduced by Fred Clark and used to shorten "slacker activism") (as cited in Christensen, 2011), which refers to the political activities that have little effect in real-life settings and they are only implemented, in order to satisfy the participants of being engaged in an online activity, "the feel-good online activism that has zero political or social impact" as characteristically contends Morozov (2009). This task presupposes the integration and implementation of a number of factors that fall in the sphere of the strategic plan, which will be discussed in the next section.

\section{The role of feedback and inclusion in the implementation of e-Parliament services}

The questions, which were set out in the prior sections, ignite an interesting conversation about the role of a contemporary parliament fomenting a political transformation; nevertheless, in this paper we will focus on the issue of feedback, an element in citizen participation, which embraces the whole process for an inclusive society and proves that citizens' opinions are taken seriously by parliaments. Further, we will try to outline its major components. Nowadays, "e-government has been gradually evolving into a more interactive process whereby citizen engagement through econsultation and e-participation is now being viewed as a necessary next step towards the promotion of a more inclusive society". In the past years governments were interested mostly in "the delivery and provision of online public services, and less on feedback mechanisms that allow citizens and stakeholders to engage in policy debates and consultations" (Nahleen, 2006, p. 4). 
When talking about an "interactive process", feedback is constituted of four characteristics: Inclusion, awareness, engagement and participation. This means that, both in the physical and the electronic context of citizens' participation, these are the necessary "steps" to be taken into account and none of them can be omitted for a complete participatory procedure.

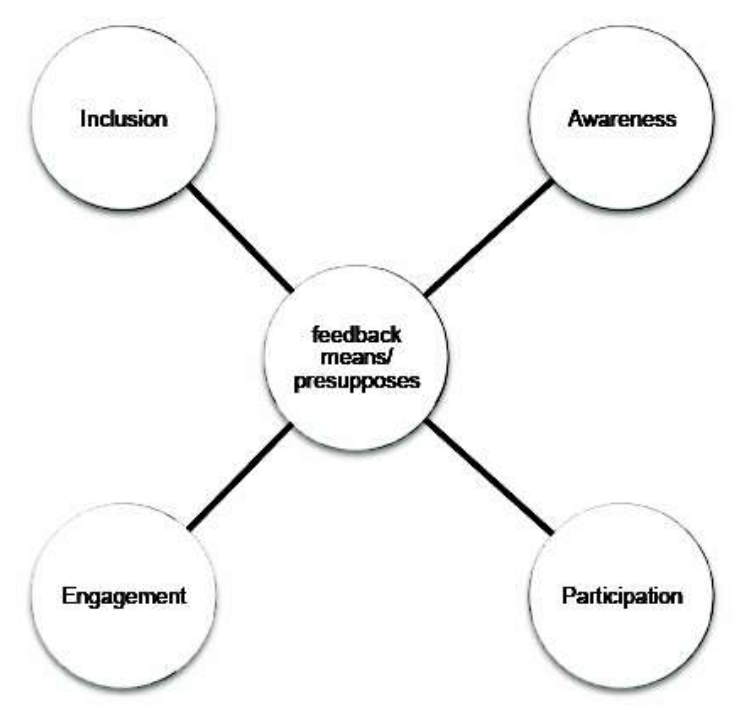

Figure 1: Representation of the 'feedback' elements

Searching in several sources about e-participation, we have come across different classifications. For example, the United Nations (UN) e-Government Survey (2008) adopts a tripletiered classification for e-participation, namely e-information, e-consultation and e-decision making. E-information overlaps with the elements of citizens' involvement (inclusion) and awareness by providing "online publishing of the official e-participation policy, listings of opportunities for online participation and electronic notification mechanisms to involve citizens" (United Nations, 2008, p. 62). E-consultation overlaps the element of engagement through "online channels", such as blogs, informal polls, instant messaging etc. (United Nations, 2008, p. 63). E-decision making evaluates "individual citizen's input" (participation) and "a government's commitment to e-participation" (feedback) (United Nations, 2008, p. 63).

A further approach by the International Association for Public Participation (IAP2) classifies public participation in five stages: those of information, consultation, involvement, collaboration and empowerment (IAP2, 2007). These five aspects are equivalent to those mentioned above and according to the classification given above, i.e. inclusion, awareness, engagement, participation and feedback. A brief analysis of these characteristics aims to portray how the whole process of feedback works both in the physical and the electronic environments.

Talking about inclusion, we are actually talking about the avoidance of exclusion. According to the Intelligent Community Forum Report (2010), "communities seek to promote digital inclusion through programs addressing access, affordability and skills" (p. 18). In the same line of thought, Nahleen (2006) goes a step further, mentioning that e-inclusion programs are not always effective by implementing online services and communications and adds that "conversely, some communities feel empowered even when individuals do not make personal use of ICT tools and services" (p. 2). This implies that parliament stakeholders should not invest merely in e-services enabling citizens' accessibility, affordability or skills; they should take steps "to e-enable existing social inclusion policies" (Nahleen, 2006, p. 11). For example, parliament stakeholders should focus on civic education by including and involving all societal groups (schools, universities, nongovernmental organizations and municipalities) in their e-participation ventures; they should reach underprivileged or hard to reach groups through fact sheets, open houses and, if possible, through cell phones - especially for citizens living in developing countries; they should defend the unequal 
gender digital divide, such as social beliefs that exclude women from participating in politics, human trafficking or pornography through the internet related to women, or exclusion of women living in rural areas. This can be achieved by enacting legal frameworks to promote equal access for women and men both in physical and electronic context, by implementing "a gender-conscious ICT policy development", by enabling a "closer cooperation between electoral bodies and gender groups" etc. (United Nations, 2010, p. 91).

Awareness and inclusion are interconnected factors, which can ignite citizens' interest for constructive participation either in a physical context or in an electronic one. The IAP2 (2007) proposes possible techniques for raising citizens' awareness based on the implementation of public comments, focus groups, surveys and public meetings. The issues that raise citizens' awareness are daily social or political issues and problems that citizens are willing to discuss and take part. Some examples outline succinctly the degree of awareness that has been raised by citizens. An evaluation report of the VoicE project shows that a low participation of MEPs (Members of the European Parliament), due to lack of time, can also result in a low percentage of citizens' participation (Scherer and Wimmer, 2010). A second example of citizens' awareness in using ICTs (in this case mobile telephones, e-mails and webcams) is that of the UTOPIA Trilogy project aiming at the elderly. Carmichael, Newell and Morgan (2007) refer to the implementation of narrative videos based on stories "of many older people's real experiences" that has resulted in the familiarization of elderly people with the abovementioned ICTs offered and further, in their integration in their everyday activities (p. 591).

A lot of references have adopted several patterns of citizen engagement. One of them, based on the study of Damodaran and Olphert (2006) focuses on the following dimensions: "initiator, structure, focus, scale, impact, and citizen influence" (p. 101). In the first case initiators might be either institutions or citizens, their objectives are: "enhanced civic participation, implementation of electronic service delivery and reducing social exclusion" (p. 102). Structure is divided into "formalized and organized (e.g. in exercises initiated and supported by institutions)" and "to informal and largely reactive initiatives led by concerned individuals or groups" using ICT tools such as wikis, blogs, short message service (SMS) etc. (Damodaran et al., 2006, p. 103-104). This kind of structure is also highlighted in the parliamentary-like initiatives as discussed in a prior section. The "focus" factor depends not only on the initiator, but also on the needs of the society. Usually, in developing countries the focus of initiatives is "upon improving basic living conditions", while in western countries the projects focus "upon the needs of excluded or marginalized groups" (Damodaran et al., 2006, p. 105). Issues of scale and impact pertaining citizen engagement differ, depending on the purposes and the importance of the issues. Finally, as far as citizen influence is concerned this is not influenced by the number of the stages in which citizens are involved with, namely agenda setting, analysis, shaping policy etc. (Damodaran et al. 2006). Online engagement is restricted, according to Damodaran et al., by factors such as "technical focus of ICT developments, limited practice of participatory design, role conflicts and role boundaries, knowledge skills and high perceived costs" (p. 121). At the other end, Rhodes (2011) notes that five effective ways to encourage online engagement are to "use mixed media", "to keep the community informed about the latest updates", "to email newsletters", "to maintain one-to-one contact" and "ask questions that matter to the community". The use of mixed media enables everyone to participate, keeping constant contact with the participants and keeping them informed with up-to-date notifications not only enables a closer relationship, but also assures a long-term engagement. Not to mention, the youth portal of the German Bundestag that rewards young people, who take part in several online activities (e.g. e-polls), with a point system and finally the ability to visit the German Bundestag. Finally, "asking questions that matter to the community" enables the better planning of further ventures. What matters most for Rhodes (2011) is the use of "simple questions". In the same vein, the former Vice-President of the European Commission, Margot Wallström pleads for communication between politicians and citizens in plain language (Power, 2010). 
Following, the use of the term "participation" it is implied that "citizen participation" is not only in a physical context, but also in the framework of e-participation. Participation is the end result of the abovementioned stages of inclusion, awareness and engagement. Participation and decisionmaking are terms that overlap and supplement one another, because the origin of the word "participation" actually means "take part". To this extent, citizens are able to affect decisively the policy making through the procedure of participation. According to Smith and Dalakiouridou (2009), participation "relates to inputs to policy-and decision-making for political or public policy purposes" affecting any stage of policy lifecycle both in formal or informal context (p. 2). They also add that participation is not related to democracy, but it fosters representative democracy (Smith et al., 2009). On the other hand, "citizen participation in the political process is considered highly important to foster greater government accountability, transparency and responsiveness" and the ICT tools provided can foster participatory democracy (Milakovich, 2010, p. 7). The abovementioned facts show that citizen participation - either in formal or informal context, either in physical or an ICT-enabled context - is able to promote both representative and participatory democracy. Citizen participation is the means for highlighting not only the political representation of a parliamentarian, but also the participatory potential of every citizen. Moreover, citizen participation can establish a two-way collaboration and a long-term cooperation between parliamentarians or parliaments, in general, and citizens. The 3Cs' scheme, incorporating "coordination, collaboration and cooperation", confirms the criteria mentioned above and corresponds with the components of inclusion, awareness, engagement and participation.

Coordination is linked with the procedure of inclusion and awareness describing the effort of parliaments to coordinate and group citizens according, for example, to age criteria, or to criteria relating to the degree of their digital literacy. These steps - necessary to be taken - will facilitate a better construction and organization of the activities, which are to be implemented.

Collaboration is associated with the procedure of engagement. The word itself means "work together" and presupposes the conduct of common activities between parliamentarians and citizens. The results of this kind of collaboration are able to lead - if, both citizens and members of parliament, are willing to be seriously and constantly engaged - to a long-term collaboration, called cooperation.

Cooperation is connected with participation and decision-making. At this phase, the members of a parliament and the citizens operate on a common base. Citizens propose some recommendations. In turn, the members of the parliament examine them, evaluate them, make the necessary modifications and apply them in case they believe that these recommendations have an added value.

Presenting the characteristics of inclusion, awareness, engagement and participation, we notice that each of them carries a two-way dependent relationship with feedback, which also permits a two-way exchange of experience, questions and speculations, opinions, recommendations, feelings and beliefs. In the case of inclusion, all societal groups (marginalized or not) anticipate parliament-led policies and operations, in order to include them in the parliamentary process and give their feedback in turn; this entails that parliaments are likely to receive a higher degree of feedback by all societal groups, regardless of their impairments, their social status or financial condition etc. In the case of awareness, citizens are dependent and wait for MEPs' feedback, in order to remain engaged in the project (as clearly stated in the evaluation of the VoicE project). Pertaining citizen engagement, the community managers are the competent stakeholders to keep contact with the participants and provide feedback for meaningful and long-term engagement. Likewise at the stage of participation, the reciprocal relationship between actors (citizens) and agents (policy makers) carries the meaning of recommendations' exchange and their adoption where applicable. Suffice to say, that the stages of engagement and participation (and respectively those of collaboration and cooperation) have the highest degree of feedback, compared to those of inclusion and awareness. This implies that the degree of interaction during engagement and participation stages is the highest. 


\section{Strategic planning for e-Parliament services}

In the figure below proposes a strategic plan which is comprised of two levels. The first level encompasses a PEST (Political, Economic, Social and Technological factors) and SWOT (Strengths, Weaknesses, Opportunities and Trends) analysis, as well as the examination of factors such as e-readiness, inter-parliamentary cooperation and ways of attracting citizens' interest.

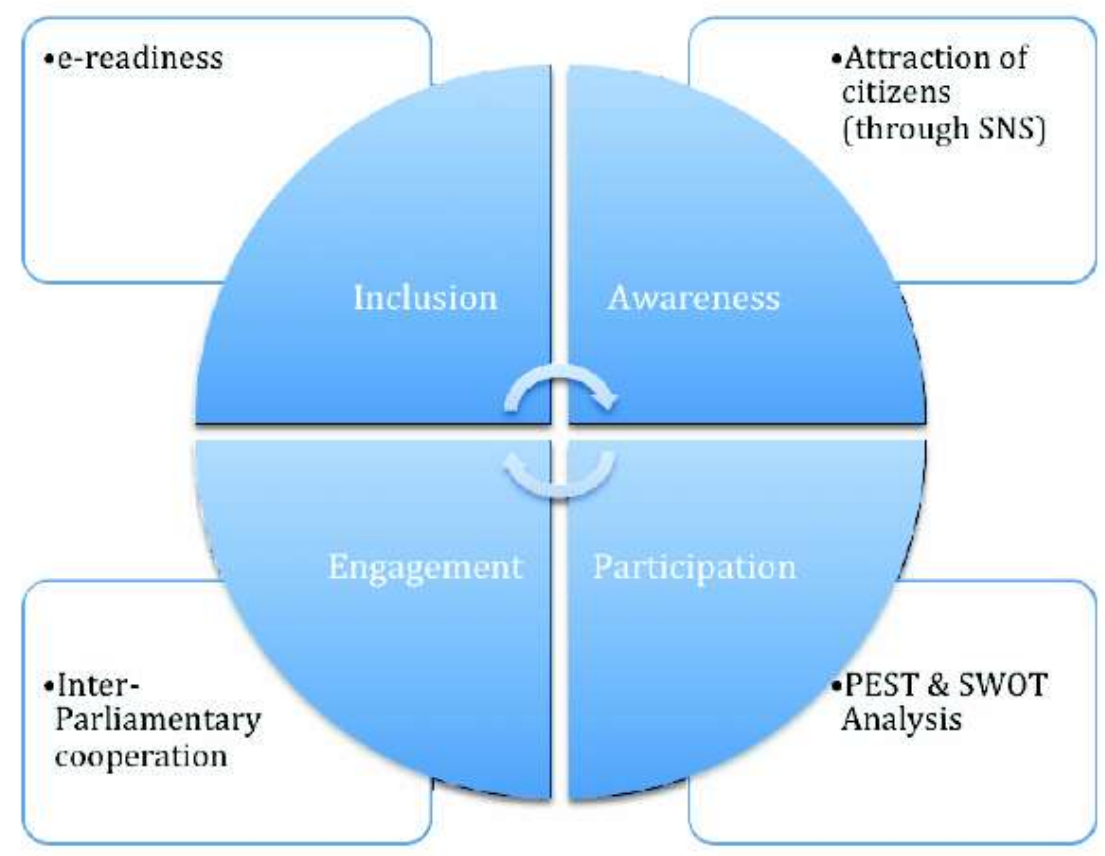

Figure 2: Strategic planning for e-Parliament services

The PEST and SWOT analysis compound the basis of the strategic planning that a parliament is obliged to review in order to ascertain, if it is feasible for further implementation of an e-service. Likewise, e-readiness plays a role of equal importance in the application of an e-parliament service. E-readiness is a significant factor to be examined in terms of parliaments and citizens, because it covers a broad spectrum of several parameters. According to the Economist Intelligence Unit (2009), an e-readiness measurement reflects "a country's ICT infrastructure and the ability of its consumers, businesses and governments to use ICT to their benefit" (p.1). This implies that ICT infrastructure includes a number of factors such as access points available to citizens, degree of computerization, networking infrastructure, availability and allocation of multilateral financial resources, a legal framework which ensures information security and privacy etc. On the other hand, the intention of human resources is a critical factor for the successful implementation of an eparliament service. This means that some of the most critical factors that need to be examined are political will and leadership, intention for governance reform, civil servants' and citizens' digital literacy, citizens' needs, as well as priorities and perceptions,.

The inter-parliamentary cooperation and the attraction of citizens' interest are two factors that should not be overlooked, in order to be able to implement suitable e-services. The interparliamentary cooperation and exchange of know-how can save valuable time by knowing in advance the policies that each parliament has adopted. Of course, every country has a different index of e-readiness and different needs; nevertheless, different age-groups have almost the same preferences as far as their engagement with interactive activities is concerned. Furthermore, the attraction of citizens' interest can be achieved with the help of social networking sites. Nowadays, a lot of people use social media for entertainment, to follow up issues of interest or contact with their friends, relatives or colleagues. Social media is popular and can serve a significant purpose by connecting parliaments with constituents. 
At a second level the whole procedure of feedback as mentioned above should be examined, taking on board all the characteristics that constitute it and examining all the parameters that need to be accomplished so as to reach the inclusive, constructive, solemn and long-term participation of citizens. Feedback is the factor that enables parliament stakeholders to gather useful information such as demographic criteria, social perceptions, degree of digital literacy, satisfaction indices of citizens pertaining an activity or initiative etc. Feedback is the crowning of inclusion, awareness, engagement and a participation procedure cycle and gives tangible data to parliaments, so as to carefully design and implement initiatives based on physical and/or electronic context and, at the same time, fostering interactivity.

The abovementioned description of a strategic plan presupposes a strong political will in terms of the parliaments in order to incite a political reform for their benefit. Citizens' inclusion in decision making either in physical or in electronic context helps people feel appreciated and accountable by the elected representatives; on the other hand, parliaments find allies during the parliamentary procedures and the elected representatives get useful feedback and, in turn, are appreciated by their constituents.

\section{Discussion and concluding remarks}

The evolution of the e-Parliament concept indicates that citizens can, and in fact should, be included in decision-making processes, through projects and services that enable everyday life citizens to actively participate and engage in interaction with members of parliament and (just as, if not more, importantly) in peer-to-peer interaction with fellow citizens. Although different, such projects can make use of technological tools, all of them should be planned to include transparent proceedings and outcomes, equal opportunities for all citizens and inclusiveness in decisionmaking.

To this end, the citizen deliberation services briefly outlined in prior sections can be ported into the context of parliamentary proceedings and implemented by parliaments in the form of novel P2C services that foster citizen participation and deliberation. What is more, these services can be combined in an elegant way with specific types of parliamentary-like initiatives already discussed; for instance, argument and discussion visualization services can be combined with youth parliaments, e-rulemaking and participatory budgeting services can be combined with social and thematic parliaments, whereas additional scenarios can be envisaged. Of course, this proposal is not a "one-service-fits-all" solution, due to the fact that strategic planning, user surveys, availability and management of human and financial resources are parameters that should be examined first.

The abovementioned factors that compose feedback testify that each factor is made up of several sub-issues to be examined and obstacles to be overcome. For example, inclusion has to, not only deal with specific demographic criteria, but also with the social beliefs about equality issues and the legal framework of a country concerning equality. Moreover, the strategic plan that should be followed for each age-group is different. For example, the narrative video works better for elderly people who are not familiar with ICT tools. For younger people a different approach is required. As far as the issue of awareness is concerned, the springboard for citizens' engagement should be initiated by the members of a parliament first as an effort to approach their constituents. The "engagement concept" should be based on the "think big, start small" concept. This means that, despite the fact that parliament stakeholders and ICT designers might like making grandiose plans for the implementation of e-services, reality is different than it seems. Sometimes, simple eservices and plain language work better for the engagement of citizens. Of course, this does not mean that we will stop searching for the implementation of more intriguing e-services in order to engage citizens in the long run. Moreover, the distinction between formalized and organized initiatives and informal and reactive ones overlaps with the already mentioned review of the parliamentary-like initiatives. Therefore, we conclude that engagement initiatives exist and run both in physical and electronic contexts, depending on the ways that citizens prefer to express 
themselves. Finally, participation fosters representative and participatory democracy and also establishes a two-way collaborative and cooperative relationship between politicians and citizens.

The whole procedure of feedback has proven that e-parliament services are not a panacea for creating P2C services unless they don't allow feedback to citizens. They rather function as a supplementary venture, which: (i) does not allow for the substitution of representative democracy with direct democracy, (ii) does not replace parliament-like initiatives which run in physical contexts with parliament-like initiatives which run in a website, (iii) reinforces participatory democracy, (iv) enables the members of parliament to apply citizens' recommendations if they judge so.

This last factor leads us a step further examining parliamentarians' and citizens' attitudes. Unwin (2010) characteristically states in his paper about the moral implications of ICT implementation in e-government initiatives that: "no amount of e-government technology (...) will actually make a government change its attitudes and approaches towards its citizens, unless that government has (...) decided to adopt new ethical stances towards such concepts as transparency, equity, and fairness" (p. 9). He, also, adds that "if e-government initiatives are to benefit citizens, they must be based on pre-existing relationships of trust between governments and citizens" (p. 9). Citizens, in turn, should adopt new ethical stances. In addition, Professor Papanis concludes that "the acute individualism excludes social action. Moreover, the depreciation towards politics and social movements reinforces social desolation and it favors isolation. (...) Lack of trust and solidarity to our fellow man -combined with indifference in politics- foresee the decomposition of the social fabric" (as cited in Varagouli, 2010, p. 94-95). A new issue is raised with this point, making obvious that parliamentarians' and citizens' attitudes should be reciprocal. The members of a parliament are not the only ones to blame. Due to the fact, that the established relationship between parliamentarians and citizens is bidirectional, both sides are responsible for the existence of an indifferent mentality and for any kind of extreme expression. This may stem from the electorate's ignorance about its obligations and rights. Of course, this is an issue for further discussed in another research paper.

A number of important research issues arise, following the initial overview and proposals made in this paper: firstly, to elaborate on the top-level objectives, benefits and measurable outcomes that can be expected from the introduction of such novel parliament-to-citizen services; secondly, to investigate in detail the service contents, service provision and citizen participation workflows; and thirdly, to explore the political, organizational and legal issues that arise on the side of parliaments, as well as the socio-cultural issues that arise on the citizen side, for successful adoption of these novel service offerings. These issues constitute an agenda of further research work, with an overall objective of designing citizen-centric deliberative projects and services that can re-establish the connection between parliaments and citizens.

\section{References}

Armit, A. A. (2007). Public Participation in Canada. The Role of Parliament. Retrieved October 27, 2009, from http://centroparlamentario.org/asia/Docs/China/Public\%20Participation\%20in\%20Canada\%20and\%20the\%20Role\%2 0of\%20Parliament.pdf

Beetham, D. (2006). Parliament and Democracy in the Twenty-First Century: A Guide to Good Practice. Geneva: InterParliamentary Union. Retrieved October 10, 2009, from http://www.ipu.org/PDF/publications/democracy en.pdf

Blackadder, J. (2009). New Democracy: Putting People Back into Politics. NSW: NewDemocracy Foundation. Retrieved November $11, \quad 2009, \quad$ from http://www.newdemocracy.com.au/ndf/docs/cp project/newDemocracy Citizens Parliament Handbook.pdf

Bose, J. (2008). Using Information Technology to Increase Citizen Participation. In J. Bose (Ed.), Participatory Budgeting: Concepts and Country Experiences (pp. 109-117). Hyderabad, India: Icfai University Press. Reprinted with permission by: http://mrsc.org/

Carmichael, A., Newell, F. A. \& Morgan, M. (2007). The efficacy of narrative video for raising awareness in ICT designers about older users' requirements. Interacting with Computers, 19, pp. 587-596. Doi: 10.1016/j.intcom.2007.06.001

Cheibub, J.A. \& Limongi, F. (2002). Democratic Institutions and Regime Survival: Parliamentary and Presidential Democracies Reconsidered. Annual Review of Political Science, 5, 151-179. Retrieved November 2, 2009, from http://www.cis.yale.edu/leitner/resources/docs/2001-19.pdf 
Christensen, S. H. (2011, February). Political activities on the Internet: Slacktivism or political participation by other means? First Monday, Vol. 16, No 2-7. Retrieved February 8, 2011, from http://firstmonday.org/htbin/cgiwrap/bin/ojs/index.php/fm/article/viewArticle/3336/2767

Coglianese, C. (2004). E-Rulemaking: Information Technology and Regulatory Policy. Regulatory Policy Program Report No. RPP-05. Massachusetts: Harvard University. Retrieved February 26, 2010 from http://www.hks.harvard.edu/mrcbg/rpp/erulemaking/papers reports/E Rulemaking Report2004.pdf

Damodaran, L. \& Olphert, W. (2006). Modelling Citizen Engagement. In R. Harper (Ed.), Informing Digital Futures. Strategies for Citizen Engagement (pp. 101-120). Dordrecht: Springer. Retrieved February 26, 2011, from http://www.springerlink.com

Damodaran, L. \& Olphert, W. (2006). Citizen Engagement in ICT Design: The Challenge. In R. Harper (Ed.), Informing Digital Futures. Strategies for Citizen Engagement (pp. 121-145). Dordrecht: Springer. Retrieved February 26, 2011, from http://www.springerlink.com

Economist Intelligence Unit (2009). E-readiness rankings 2009: The usage imperative. London, New York, Hong Kong: IBM. Retrieved August 23, 2010, from http://graphics.eiu.com/pdf/E-readiness\%20rankings.pdf

EU Committee of the Regions (2007). Summary Report of the European Citizens' Panel. A Citizens' Perspective on the Roles for Rural Areas in Tomorrow's Europe. Brussels: EU Committee of the Regions. Retrieved November 18, 2009, from http://www.citizenspanel.eu/images/final report/en/annex 07-1 en.pdf

Europa (n.d.). Europa Glossary: Subsidiarity. Retrieved February 26, 2010, from http://europa.eu/scadplus/glossary/subsidiarity en.htm

Fujitsu (n.d.). Fujitsu implements Real-Time Pocket Office to the Finnish Parliament. Retrieved January 18, 2010, from http://www.fujitsu.com/fi/news/pr/20050607-en.html

Holzner, M, Schepers, J., Scherer, S. \& Karamagioli, E. (2009). Beyond Web 2.0 - What Serious Games, Semantics and Social Networks can contribute to eParticipation. Retrieved June 21, 2010, from http://www.give-yourvoice.eu/downloads/VoiceS Paper eChallenges2009.pdf

IPEX Brochure (n.d.). Interparliamentary EU Information Exchange.

Inter-Parliamentary Union (March, 2009). Guidelines for Parliamentary Websites. Geneva: Inter-Parliamentary Union. Retrieved October 10, 2009, from http://www.ipu.org/PDF/publications/web-e.pdf

Islam, R. (2007). Preface. In A. Shah (Ed.), Participatory Budgeting. Washington D.C.: The World Bank. Retrieved February 26, 2010, from http://siteresources.worldbank.org/PSGLP/Resources/ParticipatoryBudgeting.pdf

Intelligent Community Forum (May 17, 2010). The Top Seven Intelligent Communities of 2010. The Education Last-Mile: Closing the Gap From School to Work. Retrieved February 17, 2011, from https://www.intelligentcommunity.org/clientuploads/PDFs/TopSevenIC-2010.pdf

Milakovich, E. M. (2010). The Internet and Increased Citizen Participation in Government, JeDEM, 2 (1), pp. 01-09. Retrieved February 27, 2011, from http://www.jedem.org

Moynihan, D. P. (2007). Citizen Participation in Budgeting: Prospects for Developing Countries. In A. Shah (Ed.), Participatory Budgeting. Washington D.C.: The World Bank. Retrieved February 26, 2010, from http://siteresources.worldbank.org/PSGLP/Resources/ParticipatoryBudgeting.pdf

Morozov, E. (May 19, 2009). The brave new world of slacktivism. Foreign Policy. Retrieved February 24, 2011, from http://neteffect.foreignpolicy.com/posts/2009/05/19/the brave new world of slactivism

Nahleen, A. (April, 2006). An Overview of E-Participation Models. Geneva: United Nations. Retrieved February 26, 2011, from http://unpan1.un.org/intradoc/groups/public/documents/un/unpan023622.pdf

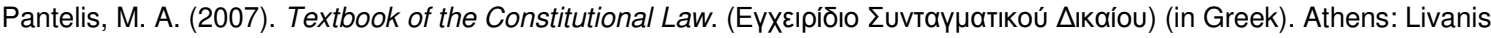

Power, A. (2010). EU Legitimacy and New Forms of Citizen Engagement. Electronic Journal of e-Government. Vol. 8, Issue 1-2010, (pp. 45-54). Retrieved February 26, 2011, from http://www.ejeg.com

Rhodes, M. (2011, February 14). 5 Ways to Encourage Online Engagement. [Web log comment]. Retrieved from http://socialmediatoday.com/mattrhodes/270027/5-ways-encourage-online-engagement (2011, February 16)

Scherer, S. \& Wimmer, A. M. (2010). A Regional Model for E-Participation in the EU: Evaluation and Lessons Learned from VoicE. Lecture Notes in Computer Science, Vol. 6229/2010, pp. 162-173. Doi: 10.1007/978-3-642-15158-3_14

Schlosberg, D., Zavestoski, S. \& Shulman, S. W. (2007). Democracy and E-Rulemaking: Web-Based Technologies, Participation, and the Potential for Deliberation. Journal of Information Technology and Politics, 4 (1), 37-55. Retrieved November 12, 2010, from http://people.umass.edu/stu/eRulemaking/JITP4-1 Democracy.pdf

Smith, S. \& Dalakiouridou, E. (March, 2009). Contextualising Public (e)Participation in the Governance of the European Union. European Journal of ePractice, No 7. Retrieved February 28, 2011, from http://www.epractice.eu/files/7.1.pdf

Staiou, E.R., Papaloi, A. \& Gouscos, D. (July, 2010). E-Parliaments 2.0: Opening the Gates to Citizens. The use of social media in parliamentary websites. Paper presented at the IAMCR Conference 2010, Braga, Portugal.

Stapleton, A. (2004). Serious Games: Serious Opportunities. Paper presented at the Australian Game Developers' Conference, Academic Summit, Melbourne, VIC. Retrieved November 12, 2010, from http://andrewstapleton.com/wpcontent/uploads/2006/12/serious games agdc2004.pdf

Teliasonera (April 20, 2005). Press Release: TeliaSonera Finland to provide the Parliament of Finland with Voice and Mobile Data Services. Retrieved January 18, 2010, from http://feed.ne.cision.com/wpyfs/00/00/00/00/00/05/C7/66/wkr0007.pdf

The Library of Parliament (2007). Library of Parliament: Service Guide. Retrieved January 18, 2010, from http://lib.eduskunta.fi/dman/Document.phx?documentld=yx29207102428846\&cmd=download 

http://www.ukcod.org.uk/index.php?title=UK Citizens Online Democracy

United Nations (2008). UN E-Government Survey 2008. From E-Government to Connected Governance. New York: United Nations. $\quad$ Retrieved $\quad$ February $26, \quad$ 2011, from http://unpan1.un.org/intradoc/groups/public/documents/un/unpan028607.pdf

United Nations (2010). E-Government Survey 2010. Leveraging E-Government at a Time of Financial and Economic Crisis. New York: United Nations. Retrieved February 26, 2011, from http://unpan1.un.org/intradoc/groups/public/documents/un/unpan038851.pdf

United Nations, Inter-Parliamentary Union, Global Centre for ICT in Parliament (2008). World e-Parliament Report 2008. Geneva: United Nations. Retrieved October 15, 2008, from http://www.ictparliament.org/wep2008/wep2008.zip

United Nations \&Inter-Parliamentary Union (2010). World e-parliament Report 2010. New York: United Nations. Retrieved April 10, 2010, from http://www.ictparliament.org/wep2010/wep2010.zip

Unwin, T. (2010). ICTs, Citizens, and the State: Moral Philosophy and Development Practices. EJISDC 44, 1, pp. 1-16. Retrieved February 24, 2011, from http://www.ejisdc.org/ojs2/index.php/ejisdc/article/viewFile/744/337

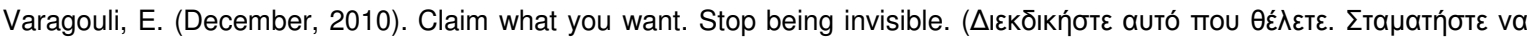

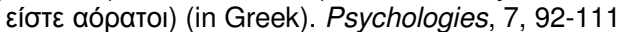

Wampler, B. (2007). A Guide to Participatory Budgeting. In A. Shah (Ed.), Participatory Budgeting. Washington D.C.: The
World
Bank.
Retrieved
February
26 ,
2010 ,
from http://siteresources.worldbank.org/PSGLP/Resources/ParticipatoryBudgeting.pdf

\section{Internet resources}

Internet resources have been last checked on $28^{\text {th }}$ April 2011.

Debategraph (http://debategraph.org/)

Hear From Your MP (http://www.hearfromyourmp.com/)

HUWY project (http://www.ep-momentum.eu/eParticipationProjects/HuWY/tabid/99/Default.aspx)

International Association for Public Participation (http://www.iap2.org/)

They Work For You (http://www.theyworkforyou.com/)

VIDI Project (http://www.vidi-project.eu/)

VoiceS Project (http://www.give-your-voice.eu/)

WAVE Project (http://wave-project.eu/)

WeGov Project (http://www.wegov-project.eu/)

Write To Them (http://www.writetothem.com/)

\section{About the Authors}

\section{Aspasia Papaloi}

Aspasia Papaloi is a PhD Candidate in the Faculty of Communication, Education and the Mass Media of the University of Athens and a research fellow of the New Technologies Laboratory in Communication, Education and Mass Media. In 1999, she graduated from the Aristotle University of Thessaloniki with a bachelor in German Language and Literature. In 2006, she completed her postgraduate studies in Rhodes (University of the Aegean, Faculty of Humanities, Department of Preschool Education and Educational Planning), obtaining a MA in "Models of Designing and Planning of Educational Units" and with specialization in "Management of Information and Communication Technologies". Her dissertation was based on informal learning and in particular on the educational portals of the Hellenic Parliament and the ways of advancing its interactive activities. As far as her interests are concerned e-parliaments, e-government and e-participation is the focal point of her current research.

\section{Dimitris Gouscos}

Dimitris Gouscos is a Lecturer with the Faculty of Communication and Media Studies of the University of Athens and a research fellow of the Laboratory of New Technologies in Communication, Education and the Mass Media, where he contributes to co-ordination of two research groups on Digital and Reflective Games-Based Learning and Electronic Governance, Digital Deliberation and Civic Media. He holds a BSc (1990) and a PhD (1998) from the Dept. of Informatics and Telecommunication of the University of Athens. He has co-ordinated the digital games-based learning research group of the EPINOISI R\&D project for production of digital games-based learning material for students with mild intellectual 
disability and the development of the Magic Potion digital game for learning, which received the Comenius Edumedia Medal in June 2009.

${ }^{1}$ Full text of Anders' Johnsson speech available at: Beetham, D. (2006). Parliament and Democracy in the Twenty-First Century: A Guide to Good Practice. Geneva: Inter-Parliamentary Union

2 "The principle of subsidiarity is defined in Article 5 of the Treaty of Lisbon establishing the European Community. It is intended to ensure that decisions are taken as closely as possible to the citizen (...)". Available at: http://europa.eu/scadplus/glossary/subsidiarity en.htm

${ }^{3}$ For more details: http://www.hearfromyourmp.com

${ }^{4}$ For more details: http://www.theyworkforyou.com

${ }^{5}$ For more details: http://www.writetothem.com 